\title{
BMA votes to end investment in fossil fuels
}

$\mathrm{T}$ The British Medical Association (BMA) set an international precedent with a vote to end its investment in fossil-fuel companies. The motion also urged the BMA to switch its electricity supply to renewable sources and to help create an alliance of health care bodies to promote the health benefits of reducing greenhouse gasses.

Dr. Jane Richards, a retired physician from Exeter, Devon, United Kingdom, who put forward the motion at the June annual meeting, said she wanted to promote more understanding of the health impact of climate change. In 2009, The Lancet called climate change "the greatest threat to human health in the 21 st century," and Richards said illnesses such as diabetes and heart disease have been linked to high carbon emissions.

Divesting from fossil fuel companies is important for the BMA's credibility as it steps up efforts to advocate for reductions in carbon emissions, added Richards. "People can be very two-faced, they say something matters, but then you look at where they get their money. This makes the point that we mean it."

The BMA is the world's first large medical organization to approve such a motion, but the money will not be pulled right away. The divestment part of the motion was passed "as reference," meaning that it has the support of the members, but it is up to the BMA's administration to decide whether it is financially feasible. There is no time frame either.

Richards says she chose this route to make the motion more palatable for those concerned about the potential financial loss. "Without the 'reference' option, it probably would have lost."

But those concerns may be misplaced. An analysis by the investment management firm Aperio Group found essentially no difference in the rate of return, or amount of risk, from a nocarbon portfolio. And HSBC Bank Canada estimates that, if governments stick to their climate targets of keeping atmospheric carbon below 450 ppm, much of the existing fossil-fuel reserves will not be used, leading to a loss in market value of up to $60 \%$ for big oil and gas companies like Statoil, BP and Shell. The president of the World Bank, Jim Yong Kim - himself a former physician — backed withdrawing funding from oil and gas companies at the World Economic Forum in Davos, Switzerland, earlier this year.

Divestment campaigns have historically been successful in driving social change, such as ending apartheid in South Africa. Fossil-fuel divestment campaigns are now gaining steam at universities, municipalities and religious institutions around the world.

Kelsey Mech, national director of the Canadian Youth Climate Coalition, says the Fossil Free Canada movement has 20 active campaigns urging divestment, mostly at Canadian universities.

The Canadian Medical Association (CMA) said that members are able to tailor their individual investment portfolios to reflect their values. "Socially responsible investments (SRIs) are of some concern to the CMA and its members as we've heard at annual meetings. Our financial services firm, MD Physician Services, through its open architecture, offers SRIs to all its clients," the CMA stated in an email.

Dr. Courtney Howard, an emergency department physician in Yellowknife, NWT, wants the association to do more. "There have been innumerable calls for doctors to act on climate change," she said. "The CMA has a very good position statement, but hasn't done much to act on it."

She authored three motions on climate change that were presented at the 2013 CMA General Council, asking the association to report how much of its portfolio was invested in fossil fuels, to explore the implications of a fossil-free portfolio and to calculate and report the association's travel-related carbon footprint. All three were defeated, but Howard plans to try again at the 2014 General Council meeting in August.

She thinks she may have more success this year, as events like the BMA vote show that there has been considerable movement in the international community in the past year. She also plans to make her pitch more reassuring this time, presenting it less as a response to a disaster, and more as simply the way the profession is moving. And she will make it clearer that having a fossil-free portfolio would be an individual option, which members could choose depending on where they are in their retirement planning.

In the end, though, it boils down to a simple moral question, she says. "How can we profit from something that we know is going to harm health?" — Brian Owens, St. Stephen, NB

CMAJ 2014. DOI:10.1503/cmaj.109-4857 